\title{
CO-CREATION APPLIED TO INNOVATION FOR BRANDING ONLINE DISTANCE EDUCATION
}

\author{
Dr. Farooq HAQ \\ ORCID: 0000-0002-1620-9226 \\ Faculty of Management \\ Canadian University Dubai \\ Dubai, UNITED ARAB EMIRATES
}

Received: 12/07/2020 Accepted: 17/03/2021

\begin{abstract}
This exploratory qualitative research investigates branding innovation for online distance education in Australian regional universities. The purpose is to apply co-creation to specify the type of innovation and branding approach for online distance education. The research purpose was achieved by studying two regional universities in Australia. The data was collected through in-depth interviews. Convenient sampling was employed to finalize the total sample of 36 managers, administration officials, technical staff and academics in both universities. Data analysis was conducted by thematic analysis. Research findings emphasized the importance of continuous innovation based on co-creation and cooperative branding for online distance education. Findings of this qualitative study were constructed on direct interviews conducted with internal stakeholders indicating three emerging themes: need for flexible education, growing market opportunities and the role of technological support. The paper argues that continuous innovation with cooperative branding will enhance academic and competitive performance of regional universities. Branding could be strategized by point-of-parity and cooperation replacing point-of-difference approach in the education industry. Research outcomes cover a gap in literature on branding online distance education for innovation based on co-creation. This study could be replicated in other countries including Turkey to investigate factors affecting innovation for branding distance education.
\end{abstract}

Keywords: Distance education, branding, online teaching, co-creation, continuous innovation.

\section{INTRODUCTION}

Distance learning became the trend in the last century especially for people working and seeking flexible education to develop their careers and professions (Kara, Erdoğdu, Kokoc, \& Cagiltay, 2019; Ozbek, 2015; Yuzer, 2014). Online education as an innovation emerged as a most viable channel for distance teaching and learning in this century (He, Xu \& Kruck, 2019; da Silva, Barbosa \& Gomes, 2019; Fagerstrom \& Ghinea, 2013; Garrett, 2004). The distance learning based on online education also provided an opportunity to non-metropolitan or regional universities to compete with metropolitan or capital city universities on similar grounds of education quality and service delivery. Students opting for distance learning were not motivated by the size, reputation or location of the campus, but the quality of education and service embedded with their online classes and online assessments (Ozbek, 2015; Granitz \& Greene, 2003).

The importance of online education has re-emerged recently during the Covid-19 pandemic. The global impact of Covid-19 showed a massive influence on education and the way it had been offered and delivered across the globe. Hence, transforming many educational institutions towards online distance learning. This global transformation towards adapting online distance education platforms changed the marketing competition mechanisms as well. Governments around the world have already been cautious about the emergence of online distance education (da Silva et al., 2019; Yuzer, 2014; Garrett, 2004). Therefore, new education policies have been discovered and applied to manage online distance education. In Australian Higher Education context, the Bradley Report delivered by Bradley, Noonan, Nugent and Scales (2008) is still recognized as the defining moment that stressed upon reforms to strategise research and education innovation. Australian 
regional universities have been following the report's recommendations by readjusting the online education services for their clients enabling them to sustain the current crisis from the Covid-19 pandemic.

The inherent weakness of socio-economics due to remoteness impedes the expansion of higher education in regional areas. The slim market base and health crisis impends the survival of regional universities. A key feature of regional universities is the physical distance from major population centres. Today's world is getting more virtually interconnected hence making online education a viable option. While regional universities in Australia organise highly skilled people to embrace online technological development, a clear vision is vital for them to embrace innovation in a dynamic IT (Information Technology) environment as a managerial challenge (Siemens, 2013).

This research is motivated to study innovation for branding distance education based on co-creation among providers, consumers and other stakeholders involved with universities. The research direction of the paper is entrenched in the concern for universities accepting continuous or radical innovation for effective implementation of online education. The purpose of this paper is to study how innovation for online education could be achieved by following the innovation model from Abernathy and Clark (1995)? The overarching research question is: with the purpose to enhance marketing competencies by co-creation, should regional universities adopt brand positioning for their online services based on challenging or cooperative marketing strategies? Specific elements could be derived from literature and used as indicators to co-create and use in conducting interviews with stakeholders of the two selected regional universities in Australia.

\section{LITERATURE REVIEW}

\section{Distance Education Innovation}

The innovation in services such as education always opens the debate towards the types of innovation to be selected and applied (Kara et al., 2019; Siemens, 2013; Gallouj \& Weinstein, 1997; Afuah \& Bahram, 1995). Radical innovation is known as discontinuous or disruptive innovation, likewise continuous innovation could be similar to non-radical or incremental innovation (Smith, Brand \& Kinash, 2013; Walter, Garrison \& Anderson, 2013; Corkindale \& Belder, 2009). Walter, Garrison and Anderson (2013) argued that traditional universities need to follow market changes of higher education by incubating disruptive communication and learning technologies, which is possible by continuous innovation in education services.

This research uses the types of innovation with terms such as radical and continuous innovation. Radical innovation is classically defined as the creation of a totally new product, i.e., one defined in terms of characteristics unconnected with those of an old product' (Gallouj \& Weinstein, p.11, 1997). As a comparison, continuous or incremental innovation is 'the addition of one or two new characteristics to a certain type of product, either by directly mobilising certain competences, or by adding new technical characteristics' (Gallouj \& Weinstein, p.12, 1997). The preceding definitions provide a guideline to apprehend the basic topics and subjects analyzed and applied in this research.

The Henderson-Clark Model is respected in innovation management, which underlines that products are made from interconnected components. The knowledge can be divided as: knowledge on components and knowledge of connections known as architectural knowledge (Henderson \& Clark, 1990). Henderson \& Clark (1990) further clarify that if an innovation adds value to both components and architectural knowledge then it is continuous, if both are cluttered then innovation is radical. Since the Henderson-Clark Model refers to physical features and functions, it is more applicable to tangible products where services are not considered equal to products (Gilbert, 2005).

The Abernathy-Clark Model presents two types of knowledge, the technological and market knowledge (Abernathy \& Clark, 1985). Abernathy and Clark (1985) further clarify that for continuous innovation the producer protects the technological and market competencies; while for radical innovation their producer does not protect any of the two since the technological and market knowledge is relevant to the education industry. The Abernathy-Clark Model was hence embraced in this paper to find the innovation that could be applied for brand positioning online distance education by regional universities in Australia. The benefits of co-creation for students and institutions presented in the conceptual model by Dollinger, Lodge and Coates (2018) will also be explored in this paper. 


\section{Brand Positioning Online Distance Education}

This century has witnessed most universities around the world adopting online teaching platforms to strengthen their distance learning products and services. Marketing and brand positioning has played a vital role in the success of online distance education (da Silva et al., 2019; Whisman, 2009; Garrett, 2004). Generally, marketers and researchers have agreed that universities need to apply competitive branding strategies for online distance education (Khanna, Jacob, \& Yadav, 2014; Granitz \& Greene, 2003). However, Garrett (2004) concluded from his study on British Universities that aggressive competitive strategies was one of the causes for the failure of the UK e-University. On the contrary, co-creation based branding strategies engaging social media and online communities are suggested to avoid confrontation and adopt cooperative marketing approach (Hajli et al., 2017). Whisman (2009) also presented internal branding as an inside-out approach for university branding based on university's engagement with stakeholders rather than traditional advertising campaigns based on symbols and themes. Likewise, cooperative branding based on co-creation among communities on social media are favourably influenced by brand loyalty and trust (da Silva et al., 2019; Kamboj, Sarmah, Gupta \& Dwivedi, 2018; Rinaldi \& Cavicchi, 2016).

Branding is known as a process that creates a strategic identity to pass the information to a specified audience (Suomi \& Jarvinen, 2013; Hajli, Shanmugam, Papagiannidis, Zahay, \& Richard, 2017; Keller, 2003). A brand is known as a winner if the organisation behind the brand can recognize needs and wants of its target public (Keller, 2003). Most brand experts view brand as the essential asset as being the 'good will' (Aaker, 2007, p.9). Branding strategy is based on two major options, points of parity (POP) or cooperation, and points of difference (POD) or differentiation (Keller, 2003). This research appreciates brand positioning as the effort companies and universities execute to make their brand known. Keller and Lehmann (2006) presented a framework to integrate the customer-market and product-market, which was applied in this study to follow the trend in education industry and present recommendations for brand positioning online distance education. Likewise, Bowden (2011) stressed on functional and academic interactions for students as part of his relationship marketing strategy based on engaging students as customers.

\section{Branding Led by Co-creation}

Researchers have been emphasising that branding strategies need to be mapped with co-creation strategy that is developed by using social media and online brand communities with cooperative and relationship marketing (Kamboj et al., 2018; Hajli et al., 2017; Rinaldi \& Cavicchi, 2016). Galvano and Dalli (2014) categorised co-creation literature under three theoretical viewpoints: service science, innovation and technology management; and marketing and consumer research. The research conducted in this paper follows the third viewpoint of marketing and consumer research. The presence of the value co-creation experience is being observed in several industries between Business-to-Consumer (B2C), (C2B) and C2C (Ranjan \& Read, 2016; Galvano \& Dalli, 2014).

Prahalad and Ramaswamy (2013) emphasized on the co-creation experience as a ground value and as the future of innovation to be a winner in the upcoming influential experience economy that includes education. The experience of an individual with co-creation provides value resulting from the engagement of an individual at a given place and time and within the context of a special activity or experience. The co-creation depends not only on outsourcing or as the minimum adaptation of goods or products, but it demonstrates the process through which customers interact with the company and generate their own experience with the service provided (Fagerstrom \& Ghinea, 2013; Prahalad \& Ramaswamy, 2013). Kamboj et al. (2018) also advocated that branding strategies based on co-creation not only make the brand powerful, but also increases the brand loyalty from customers. Furthermore, it can be stated that co-creation and engagement with students combine students' abilities with institutional capabilities to simplify various educational processes leading towards more effective performance and innovation (Prahalad \& Ramaswamy, 2013; Bowden, 2011).

Dollinger, Lodge and Coates (2018) explained that value co-creation depends on co-production of value and value-in-use, where co-creation enables institutions and students to collaborate for enhancing the study experience and students' capability to perform as partners. Similarly, Ranjan and Read (2016) elaborated that 
value co-creation is structured on double dimensions of the co-production of value: the value proposition is initiated together with customers, and, value-in-use: where value is outside the production process embedded in the consumption of the value. Value co-creation in education adjusts the marketing strategy based on consumer preferences and student behaviour (Elsharnouby, 2015; Fagerstrom \& Ghinea, 2013; Prahalad $\&$ Ramaswamy, 2013). This paper adapts the first dimension of value co-creation as in the co-production of value in order to present suggestions for branding online education by universities.

\section{Online Education in Regional Universities}

Similar to the global education industry, all Australian Universities are contending in today's arena of online teaching (Bradley et al., 2008). The regional and remote universities take online distance education as a tool to restructure their own markets aiming to achieve sustainability to match with other competitive establishments. Due to the educational reforms, regional universities found the opportunity to enter the competition for online education. The regional institutions were traditionally focusing on educating regional students and some international students, generally especially those who were pursuing discounted fees or plus points to secure Australian residence from immigration.

The emergence of online learning in distance education transformed the university education market by placing all universities in the same battle field (Elsharnouby, 2015; Ozbek, 2015). This revolution has also opened a new aspect of online marketing strategies heavily relying upon online branding (Bock, Poole, \& Joseph, 2014). The celebrated universities use their reputation to brand and market their online education. Meanwhile, regional universities are facing this task to craft their own brand positioning for the new market where the competition is not confined to geographic positions. Dollinger et al. (2018) illustrated the conceptual model for co-creation in higher education signifying the collaboration among university students and the institution. The model elaborates upon the co-creation benefits for students such as: quality interaction, satisfaction and graduate capabilities. Meanwhile, the institution benefits from students' loyalty, image and student-university identification. Contrarily, research has been conducted on using co-creation for student recruitment in various universities (Fagerstrom \& Ghinea, 2013).

The application of value co-creation within both dimensions of co-production of value and value-in-use has been presented in literature as discussed above. However, there is a gap in literature on discussing coproduction based on value co-creation for branding online education for universities in general, and remote universities in particular. Therefore, Abernathy-Clark Model of innovation was adopted along with the conceptual model of co-creation in higher education presented by Dollinger et al. (2018). Since this study focuses on branding for institutions, the benefits of co-creation for institutions as mentioned above, will be further explored in this qualitative research based on interviews with stakeholders of the selected universities in Australia.

\section{METHODOLOGY}

Due to the exploratory nature of this research, a qualitative methodology was considered appropriate to reach realistic findings based on interviews with selected stakeholders of two regional universities. In order to enhance the reliability processes in data collection and analyses, the author had to be realistic with data analysis (Lincoln \& Guba (2003). Direct interviews were used to collect data and each interview transcript was analysed separately by the author to validate the findings (Alam, 2005; Miles \& Huberman, 1994). The author appreciated guidelines from Lincoln \& Guba (2003) that the existence of an objective reality is imperfectly perceived due to various limitations, hence various perspectives and opinions from stakeholders were independently recognised to enhance the impartiality and quality of the research outcomes.

This research investigated innovation for brand positioning online teaching in two regional institutes in Australia. Four respondent groups in both universities were recognized: managers, administration staff, IT experts and academics. This sampling was inspired by the sampling process adopted from the research of $\mathrm{He}$ et al. (2019) and Kara et al. (2019) selecting distance education stakeholders for their study. Furthermore, university employees were selected as respondents for this study since literature on branding and innovation has recommended them to be engaged in a university's branding process (Suomi \& Jarvinen, 2013; 
Corkindale \& Belder, 2009; Curtis, Abratt \& Minor, 2009; Abernathy and Clark, 1995). The significance of the staff members in brand positioning has been appreciated by labelling them as the 'brand champions' (Whisman, 2009, p.368). Since there was no pertinent theory available, ideas had to be inducted and hence an exploratory approach was followed and the data was analysed by adopting thematic analysis (Stake, 2013; Alam, 2005). Therefore, a qualitative methodology was adopted for effective findings and credible results.

\section{Case Selection}

In Australia, two regional universities were selected for this study, they are further described ahead. University-A is considered as the biggest institute in the territory stretched out to five campuses in isolated areas. The University was established in 2003 and being young it offers new methods for teaching and learning with wide scope for research and knowledge development. Backed by a strong history of delivering value through vocational education as well as higher education, research and social engagement, University-A is expecting reasonable growth. The university seeks to be globally appreciated as a centre for excellence in indigenous and cross-cultural knowledge, tropical knowledge and desert knowledge.

University-B is the other and reasonably new Australian University with well spread operations across Australia, starting as a College of Advanced Education and becoming a University in 1992. The university is stretched to many campuses in its regional impression and in major Australian cities, which are being managed by a wholly owned subsidiary focusing on international students. University-B is considered to be the pioneer to provide flexible distance education, mixed-mode study, eliminating differences between fulltime and part-time and on-campus and off-campus study.

\section{Direct Interviews}

The sampling criteria followed for this study were precise and the identity of respondents was known to the author, so judgmental and convenience sampling were utilized (Stake, 2013; Browne, 2005). This study did not pursue the quantity of data but sought the quality of the information. The right number of respondents or sample size was decided by the principle of saturation indicating when data collected from interviews stretches to saturation where a comprehensive picture of diverse experiences related to the research is drawn (Alam, 2005; Gibbs, Kealy, Green, Welch, and Daly, 2007).

For direct interviews, 43 stakeholders confirmed to meet and share their thoughts. Eventually, 36 interviews were conducted where the information saturation, or the qualitative isomorph was attained (Ponterotto, 2005; Lincoln \& Guba, 2003; Yin, 2011; Miles \& Huberman, 1994). The final sample for this study consisted of eight IT staff members, seven managers, eleven administration staff members and ten academics at both regional universities.

In order to collect data for this qualitative research, following questions were asked from each participant during in-depth interviews:

Q1. Please describe the product offered by your university? In your view, is online distance education a new product or an extension?

Q2. In your view, is there an innovation for brand positioning the online distance education for your university?

Q3. Do you suggest brand positioning of your online distance education based on competitive or cooperative strategies?

Q4. Please illustrate if you are provided an opportunity to communicate your feedback regarding the marketing and branding of online distance education of your university? In your view, how this feedback could be used, or is being used, in the co-creation process?

The in-depth interviews in University-A were tape recorded and notes were written by the author as well. At the end of each interview, findings were validated by triangulating hand-written notes with interview recordings. All statements from each respondent were confirmed by asking them individually to check the transcript handed after completion of the interview. The author also travelled to two different campuses of University-B for interviews and consolidated written notes after each interview. All interview transcripts were finalized after triangulating hand-written notes and audio recordings. 


\section{Data Analysis}

All respondents were questioned during interviews based on the research questions given earlier. Generally, interviews ranged from 25 to 60 minutes, during the discussion author confirmed the key statement on the spot to make sure that the exact wordings were recorded. Each transcript was read repeatedly for thematic analysis to search thoughts of interviewees associated with the research's subject (McVea, Miller, Creswell, McEntarrfer and Coleman, 2009; Stepchenkova, Kirilenko and Morrison, 2009).

As a basic requirement for qualitative data analysis, the data collected from various sources was coded (Ponterotto, 2005). Codes have been explained as 'tags or labels for assigning units of meaning to the descriptive or inferential information compiled during study' (Miles \& Huberman, 1994 p. 56). Coding is guided by research questions and directs the researcher towards new questions to arrive at research objectives, codes can be applied to words, phrases, sentences, or a paragraph (McVea et al., 2009; Alam, 2005). The completion of primary interviews and preparation of transcripts triggered the open coding process that was supported by the question-answer approach (Stepchenkova et al., 2009; Miles \& Huberman, 1994).

In the open coding process, individual interview transcript was considered while looking for patterns of meanings, including assumptions or verdicts given by interviewees. The open coding itemized and delivered colour coded pointers emerging from interviews. Inspection of all colour coded indicators led to the arrival of clear thematic labels. These labels were then linked to the related colour coded sections to which they applied in each transcript. The open coding thematic labels were drawn from the repeated and underlined ideas of each respondent and were pasted on original transcripts. Eventually, axial coding specified any relationships between codes identified during the open coding process when codes were considered more valuable compared to the data (McVea et al., 2009; Gibbs et al., 2007).

In the axial coding process, codes were considered as tags or memos written during the open coding stage (Ponterotto, 2005). The codes were scrutinized and matched to apprehend combined answers and reactions from respondents leading to a cross-case analysis established on the collected data to impartially search themes and sub-themes within coded themes. Following the exploratory research protocols, no responses were forced to be seen as part of any themes or sub-themes. The researcher did not work out origins of any theme and sub-theme before the data collection or from the literature.

All responses belonging to an institute regarding a particular question were typed and placed in a single file. Therefore, total four files, one for each question, were prepared for each university that appeared as distinct essays. In the axial coding process, the cross-transcript analysis of each of the four questions was deliberated to conclude the research themes and sub-themes. The coding for each respondent in both universities is explained below:

Table 1. Codes for Respondents in University A and B

\begin{tabular}{|c|c|c|c|c|}
\hline University & Managers & Officials & IT Staff & Lecturers \\
\hline University A & $M A 1, M A 2 \ldots$ & $\mathrm{OA} 1, \mathrm{OA} 2 \ldots$ & ITA1, ITA2 ... & LA1, LA2 ... \\
\hline University B & $M B 1, M B 2 \ldots$ & $\mathrm{OB} 1, \mathrm{OB} 2 \ldots$ & ITB1, ITB2... & LB1, LB2 ... \\
\hline
\end{tabular}

\section{FINDINGS}

The thematic analysis conducted in this paper presented three major themes: flexible delivery of online distance education, opportunities leading to market growth and quality of IT performance. The subsequent discussion highlights the creation of the three major themes separately built on sub-themes emerging directly from conversations with participants. The flexible delivery as the first theme, given in Table 2, was accepted by assimilating three sub-themes: part-time job requirements, obligations towards the family and the remote location of the place.

It was observed that around $65 \%$ of enrolled students in both regional universities were managing fulltime work, home matters and part time studies. For example, it was found that more than half female students 
in University-A had children and were around the age of 31 . Since their kids were school going to so they could manage their time to study in a university. Furthermore, challenges from unknown and unaccredited institutions offering good value packages also drove students towards flexible education from well-known institutes. Likewise, being remotely located and away from major cities were also observed recurrently as sub-themes improving the case for flexible education as a central theme.

Table 2. Flexible delivery of education themes and sub-themes

\begin{tabular}{lcc}
\hline Direct Quotes from respondents & Emerging Sub-Theme & Emerging Theme \\
\hline $\begin{array}{l}\text { Due to my causal work I was bounded to search for casual } \\
\text { studies (OA2) }\end{array}$ & Casual work & \\
Most of my external students choose online studies due to & \\
work flexibility (LB1) & & \\
I plan to study in future and go for flexible online programs & & \\
where I can manage a part-time job (ITB1) & Family Commitments & education \\
While living in regional areas we have family commitments \\
$\begin{array}{l}\text { and can't organize fulltime studies (MB1) } \\
\text { Me as a single mum, busy with kids and working, can only } \\
\text { manage an online uni degree (LA1) }\end{array}$ \\
$\begin{array}{l}\text { Most of my students opt for online studies due to the } \\
\text { remote locations (LB2) }\end{array}$ \\
$\begin{array}{l}\text { My own uni job in IT hangs on remote distances, pushing } \\
\text { students to go for online education (ITB2) }\end{array}$ \\
\hline
\end{tabular}

The second theme appreciated in this study was the opportunity leading to the market growth of online distance education. As mentioned by participants, while considering the environment, crowd, pollution, security and health in larger cities, many students choose smaller regional universities to study in a quiet, safe and healthy atmosphere. Likewise, the author was informed that the tough competition between major universities also profited regional universities as some students did not want to be the victim of cross university competition and preferred an institute of teaching and not commercial competition. The interviews also disclosed that complicated admission procedures and most metropolitan universities shifting costs to students for online distance education also attracted students towards regional universities.

Table 3. Market growth and opportunity themes and sub-themes

\begin{tabular}{|c|c|c|}
\hline Direct Quotes from respondents & Emerging Sub-Theme & Emerging Theme \\
\hline $\begin{array}{l}\text { Most of my students find big cities too crowded to focus on } \\
\text { their studies (LA2) }\end{array}$ & $\begin{array}{l}\text { Problems to study in big } \\
\text { cities }\end{array}$ & \multirow{7}{*}{$\begin{array}{l}\text { Market Growth and } \\
\text { Opportunity }\end{array}$} \\
\hline \multicolumn{3}{|l|}{$\begin{array}{l}\text { Working and studying simultaneously in metro-cities is } \\
\text { impossible for me (OA2) }\end{array}$} \\
\hline \multicolumn{3}{|l|}{ I think most students hate heavy traffic in large cities (MB1) } \\
\hline $\begin{array}{l}\text { Crazy competition in large cities damages the quality of uni } \\
\text { education (MB1) }\end{array}$ & $\begin{array}{l}\text { Cost transfer issues for } \\
\text { universities in large cities }\end{array}$ & \\
\hline $\begin{array}{l}\text { I can't study and work in a metro city too far away from } \\
\text { here (OA1) }\end{array}$ & & \\
\hline $\begin{array}{l}\text { Universities in smaller areas receive more support from } \\
\text { government compared to money making unis in capital } \\
\text { cities (OB1) }\end{array}$ & & \\
\hline $\begin{array}{l}\text { Many international students can't compete to get } \\
\text { admission in big universities (LB3) }\end{array}$ & $\begin{array}{l}\text { Admission issues in big } \\
\text { universities }\end{array}$ & \\
\hline \multicolumn{2}{|l|}{$\begin{array}{l}\text { The admission process is complicated in big universities } \\
\text { and only city kids find it easier to enter them(MB4) }\end{array}$} & \\
\hline $\begin{array}{l}\text { Reputed universities treat students as money bags and } \\
\text { do not care about admission opportunities for small } \\
\text { town kids (LA3) }\end{array}$ & & \\
\hline
\end{tabular}


The last theme emerging from interviews referred to the quality of IT (Information Technology) functions, processes and the people related to the online distance education. The effectiveness of the IT functions and people technically supporting online distance education with instant problem solving were frequently described to be essential. Furthermore, the ownership control of the lecturer and IT people was expressed by interviewees, mostly lecturers, as imperative for successful delivery of online distance education.

Table 4. IT Functionality themes and sub-themes

\begin{tabular}{lcc}
\hline Direct Quotes from respondents & Emerging Sub-Theme & Emerging Theme \\
\hline $\begin{array}{l}\text { Our job is to manage and solve any issues with IT side of } \\
\text { business that 24/7 (ITA2) }\end{array}$ & IT problem solving & \\
Without the IT guys our daily problems in online teaching & \\
could be suicidal (with a smile) (LA4) & \\
I think most students would give up online studying & \\
without diligent support from IT staff (MB4) & Regular Technical \\
It is impossible for online education to survive without IT & \\
support (LB1) & \\
No efficient technical support means no online business for & \\
our university (MB1) & IT functionality and \\
I think good technical support in regional universities make \\
us competitive against unis in capital cities (MB5) \\
The online education needs to be fully controlled by \\
academics with due support from IT Department (LB3) \\
$\begin{array}{l}\text { The IT staff must control the quality of online education } \\
\text { delivery (ITA1) } \\
\text { IT members need to be part of strategic decisions by } \\
\text { regional universities to deliver better and competitive } \\
\text { quality services (ITB3) }\end{array}$ \\
\hline
\end{tabular}

\section{Cooperative Branding for Online Distance Education}

The qualitative data analysis delivered four sub-themes emphasizing upon the importance of POP and cooperative marketing for brand positioning for distance education delivered online. The innovation offered via online education is constructed upon technological platform that is a solution for the modern generation seeking new channels for education. Likewise, digital application and technology management keep universities at similar levels to offer online education. The socio-economic background of all domestic and foreign students was depicted as alike, therefore matching marketing and promotion strategies were deliberated and applied by universities targeting similar segments.

Consequently, it can be discussed that this study signifies the credibility of POP or cooperative branding in the education industry as illustrated in Table 5. The cooperative branding or POP was also reinforced due to the equal level and quality of staff members involved in online teaching. Generally participants came from academic background and expressed the trend of Australian Universities outsourcing study materials for online education to popular universities. Due to the open access of materials and technology, respondents conveyed that universities seemed to compete more effectively on equal grounds in online education market by pursuing cooperative branding or POP. 
Table 5. Cooperative Branding for Distance Education

Themes and sub-themes

\begin{tabular}{lcc}
\hline Direct Quotes from respondents & Emerging Sub-Theme & Emerging Theme \\
\hline $\begin{array}{l}\text { All unis offering online education use similar techno } \\
\text { standards (ITA2). }\end{array}$ & Similar Technology & \\
I think all Aussie unis use Moodle or Blackboard only (LA2). & \\
$\begin{array}{l}\text { For online education all unis use similar advertising tactics } \\
\text { (MB1). }\end{array}$ & $\begin{array}{c}\text { Similar marketing and } \\
\text { promotion strategies }\end{array}$ \\
I feel that only one marketing firm is hired by all Aussie unis & \\
to promote their online education (LB2). & Similar staff quality and \\
levels & Cooperative Branding \\
The level and quality of academic staff delivering online & (POP) \\
education is similar in all Aussie unis (MB4). & \\
A similar qualification gets you a job of a lecturer or an IT \\
expert in any uni in Australia (MA1). \\
$\begin{array}{l}\text { If big unis produce good online material then regional unis } \\
\text { get in outsourced from other unis (LB2). } \\
\text { Study material for online education in all unis is quite }\end{array}$ \\
$\begin{array}{l}\text { Similar (LA3). } \\
\text { outsourcing }\end{array}$
\end{tabular}

\section{DISCUSSION AND CONCLUSION}

Tables 2 to 4 highlight how participants in this study presented their thoughts on branding online education with reference to the themes related to POP or cooperative branding. The previous discussion on vital elements of branding online education and examination of interviews direct this paper towards the fundamental strategic results as the POP being centre for brand positioning strategies for online teaching.

The research recognized three major dimensions to be contemplated for brand positioning of online education, specified as: flexible delivery, market opportunity and growth, and the role of IT staff. The POP or cooperative strategy related to brand positioning of online distance education is linked to comparisons in the technology, students' socio-economic circumstances, cooperative marketing techniques, staff quality and outsourcing of the study related products. The cooperative marketing suggested from this research agrees with the insights from Bodwen (2011), referred by him as relationship marketing. The POD or challenging strategy related to brand positioning of online distance education is linked to differentiation with respect to the age and image of the university; brand equity related to the academic staff; student services and post study employment opportunities; outsourcing of the content and managing internal customers.

\section{Theoretical Implications}

This research contributes to the literature on distance education and brand marketing linked with innovation. The concept of co-creation is uniquely used to gather information from various stakeholders to improve online distance education. The research presented three major dimensions to be contemplated for brand positioning of online education, specified as: flexible delivery, market opportunity and growth, and the role of IT staff. The classical innovation model from Abernathy and Clark (1985) was adopted in this research, which adds on the theory of innovation that for continuous innovation in online education, universities can strengthen their technological and market competencies. The continuous innovation is possible by co-creating among university students, faculty and administration; if cooperation branding is adapted as concluded by Bowden (2011).

This paper adds on to the knowledge on co-creation for higher education and supplements the benefits of co-creation. In this study, the advantages of quality interaction and satisfaction for students from co-creation outlined by Dollinger et al. (2018) are confirmed by interviews with university stakeholders who work closely with students. Likewise, universities benefiting by improving their students' loyalty and teaching quality image as suggested by Dollinger et al. (2018); is also supplemented in this research. Further insights 
are offered for the theory on branding online education adopting the cooperative branding rather than differentiated branding is recommended, based on exploring the dimension of value co-creation as in the co-production of value explained by Ranjan and Read (2016).

\section{Practical Implications}

Since universities are investing in technological innovations for more effective online distance education, this paper recommends that regional universities need to innovate through online channels for distance teaching based on the co-creation approach. Brand positioning of online education is recommended to be linked to POP or cooperative rather than POD or challenging strategies within the Australian education industry, as suggested by Bodwen (2011). Since the universities located in remote areas need to offer parity in their education services by online teaching, any efforts to differentiate or claim supremacy will damage their marketing. Online distance education needs to be considered as an extension of the education product rather than a contest for the conventional education approach. This will support the marketing of online education and improve the loyalty of students and teaching quality image of universities, as advocated by Dollinger et al. (2018). Furthermore, the well-recognised notion from Whisman (2009) that universities need inside-out approach to brand development was further established in this study.

The two specific regional universities in Australia that were examined in this research are strengthening their competitiveness and have experienced rise in student numbers. A major factor accredited for this growth emerged during interviews is the inclination of online delivery of courses as distance education and external issues including unemployment due to the economic downturn and current Covid-19 pandemic. The suggestion of cooperative branding strategies for regional universities offering online education can be mirrored for regional and non-metropolitan universities in other countries.

\section{Future Research}

As mentioned earlier, this research on online distance education has been accomplished in Australia, however, it can be applied in a global context. Future research ideas provide motivation for a similar qualitative study on online distance education to be conducted in Turkish Regional Universities. A natural future research is to confirm the reliability and validity of conclusions from this qualitative study. Findings of this research could be further quantified to improve the impact and future extensions. The quantification of findings of this qualitative study is essential for effective implication of the outcomes.

Furthermore, to strategise brand positioning effectively, the perspective of online consumers of distance learning, the students, is also vital. Hence, a future research on related topics is suggested to involve university students to understand their tastes and preferences regarding brand positioning for online distance education.

Acknowledgements: The author wishes to thank participants from Australian Universities who spared their time for the direct interviews.

\section{BIODATA AND CONTACT ADDRESS OF AUTHOR}

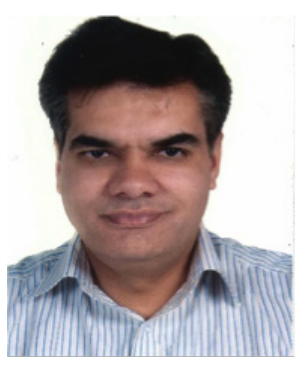

Farooq HAQ is an Associate Professor of Marketing at Faculty of Management, Canadian University Dubai in Dubai, United Arab Emirates. Dr. Haq gained his Ph.D. in Marketing from Charles Darwin University in Australia at October, 2011. His academic interest areas are specialized marketing, education marketing, marketing online teaching, and branding online education. He has 18 journal articles published in international indexes, 16 international book chapters and 26 papers submitted and presented at international conferences.

Farooq HAQ

Department of Marketing, Faculty of Management

Address: Canadian University Dubai, Postal Code 117781, Dubai, United Arab Emirates.

Phone: +971 47096204

E-mail: Farooq@cud.ac.ae 


\section{REFERENCES}

Aaker, D. A. (2007). Innovation: brand it or lose it. California Management Review, 20 (1), 8-24.

Abernathy, W. J. and Clark, K. B. (1985). Innovation: Mapping the winds of creative destruction. Research Policy, 14 (1), 3-22.

Afuah, A. N. and Bahram, N. (1995). The hypercube of innovation. Research Policy, 24 (1), 51-57.

Alam, I. (2005). Fieldwork and data collection in qualitative marketing research. Qualitative Market Research: An International Journal, 8 (1), 97-112.

Bock, D. E., Poole, S. M., \& Joseph, M. (2014). Does branding impact student recruitment: A critical evaluation. Journal of Marketing for Higher Education, 24(1), 11-21.

Bowden, J. L. H. (2011). Engaging the student as a customer: A relationship marketing approach. Marketing Education Review, 21(3), 211-228.

Bradley, D., Noonan, P., Nugent, H., \& Scales, B. (2008). Review of Australian higher education: final report [Bradley Review]. Canberra: Australian Government DEEWR.

Browne, K. (2005). Snowball sampling: using social networks to research non-heterosexual women. International Journal of Social Research Methodology, 8 (1), 47-60.

Corkindale, D., \& Belder, M. (2009). Corporate brand reputation and the adoption of innovations. Journal of Product \& Brand Management, 18(4), 242-250.

Curtis, T., Abratt, R., \& Minor, W. (2009). Corporate brand management in higher education: the case of ERAU. Journal of Product \& Brand Management, 18(6), 404-413.

da Silva, L. F. C., Barbosa, M. W., \& Gomes, R. R. (2019). Measuring participation in distance education online discussion forums using social network analysis. Journal of the Association for Information Science and Technology, 70(2), 140-150.

Dollinger, M., Lodge, J., \& Coates, H. (2018). Co-creation in higher education: Towards a conceptual model. Journal of Marketing for Higher Education, 28(2), 210-231.

Elsharnouby, T. H. (2015). Student co-creation behavior in higher education: The role of satisfaction with the university experience. Journal of marketing for higher education, 25(2), 238-262.

Fagerstrom, A., \& Ghinea, G. (2013). Co-creation of value in higher education: using social network marketing in the recruitment of students. Journal of Higher Education Policy and Management, 35(1), 45-53.

Gallouj, F., \& Weinstein, O. (1997). Innovation in services. Research Policy, 26(4), 537-556.

Galvano, M., \& Dalli, D. (2014). Theory of values creation: A systematic literature review. Managing Service Quality, 24(6), 643-683.

Garrett, R. (2004). The real story behind the failure of UK eUniversity. Educause Quarterly, 27(4), 4-6.

Gibbs, L., Kealy, M., Willis, K., Green, J., Welch, N., \& Daly, J. (2007). What have sampling and data collection got to do with good qualitative research? Australian and New Zealand Journal of Public Health, 31(6), 540-544.

Gilbert, C. G. (2005). Unbundling the structure of inertia: Resource versus routine rigidity. Academy of Management Journal, 48(5), 741-763.

Granitz, N., \& Greene, C. S. (2003). Applying e-marketing strategies to online distance learning. Journal of Marketing Education, 25(1), 16-30.

Hajli, N., Shanmugam, M., Papagiannidis, S., Zahay, D., \& Richard, M. O. (2017). Branding co-creation with members of online brand communities. Journal of Business Research, 70(1), 136-144.

He, W., Xu, G., \& Kruck, S. E. (2019). Online IS education for the 21st century. Journal of Information Systems Education, 25(2), 101-106. 
Henderson, R. M., \& Clark, K. B. (1990). Architectural innovation: the reconfiguration of existing product technologies and the failure of established firms. Administrative science quarterly, 35(1), 9-30.

Kamboj, S., Sarmah, B., Gupta, S., \& Dwivedi, Y. (2018). Examining branding co-creation in brand communities on social media: Applying the paradigm of Stimulus-Organism-Response. International Journal of Information Management, 39(1), 169-185.

Kara, M., Erdoğdu, F., Kokoc, M., \& Cagiltay, K. (2019). Challenges faced by adult learners in online distance education: A literature review. Open Praxis, 11(1), 5-22.

Keller, K. L. (2003). Brand synthesis: The multidimensionality of brand knowledge. Journal of Consumer Research, 29(4), 595-600.

Keller, K. L., \& Lehmann, D. R. (2006). Brands and branding: research findings and future priorities. Marketing Science, 25(6), 740-759.

Khanna, M., Jacob, I., \& Yadav, N. (2014). Identifying and analyzing touchpoints for building a higher education brand. Journal of Marketing for Higher Education, 24(1), 122-143.

Lincoln, Y. S. and Guba, E. G. (2003). Paradigmatic controversies, contradictions, and emerging confluences, in NKDYS Lincoln (Ed.). The Landscape of Qualitative Research, pp. 253-291. California: Sage Publications.

McVea, K. L., Miller, D. L., Creswell, J. W., McEntarrfer, R., \& Coleman, M. J. (2009). How adolescents experience smoking cessation. Qualitative Health Research, 19(5), 580-592.

Miles, M. B., \& Huberman, A. M. (1994). Qualitative data analysis: An expanded sourcebook. Newbury Park: Sage Publications.

Ozbek, E. A. (2015). A classification of student skills and competencies in open and distance learning. International Journal on New Trends in Education, 6(3), 174-185.

Ponterotto, J. G. (2005). Qualitative research in counseling psychology: A primer on research paradigms and philosophy of science. Journal of Counseling Psychology, 52(2), 126-136.

Prahalad, C.K., \& Ramaswamy, V. (2013). The future of competition: Co-creating unique value with customers. Boston: Harvard Business School Press.

Ranjan, K. R., \& Read, S. (2016). Value co-creation: concept and measurement. Journal of the Academy of Marketing Science, 44(3), 290-315.

Rinaldi, C., \& Cavicchi, A. (2016). Cooperative behaviour and place branding: a longitudinal case study in Italy. Qualitative Market Research, 19(2), 156-172.

Siemens, G. (2013). Massive Open Online Courses: Innovation in Education. Open Educational Resources: Innovation, Research and Practice, 5(1), 5-14.

Smith, D., Brand, J., \& Kinash, S. (2013). Innovation in Education. Education Technology Solutions, 56(66), 66-70.

Stake, R. E. (2013). Multiple Case Study Analysis. New York: Guilford Press.

Stepchenkova, S., Kirilenko, A. P., \& Morrison, A. M. (2009). Facilitating content analysis in tourism research. Journal of Travel Research, 47(4), 454-469.

Suomi, K., \& Jarvinen, R. (2013). Tracing reputation risks in retailing and higher-education services. Journal of Retailing and Consumer Services, 20(2), 207-217.

Walter, A., Garrison, R. and Anderson, T. (2013). Adopting disruptive technologies in traditional universities: Continuing education as an incubator for innovation. Canadian Journal of University Continuing Education, 25(1), 13-44.

Whisman, R. (2009). Internal branding: a university's most valuable intangible asset. Journal of Product \& Brand Management, 18(5), 367-370.

Yin, R. K. (2011). Applications of Case Study Research. Thousand Oaks: Sage Publications.

Yuzer, T. V. (2014). Handbook of Research on Emerging Priorities and Trends in Distance Education: Communication, Pedagogy, and Technology: Communication, Pedagogy, and Technology, (Ed.). Pennsylvania: IGI Global. 